\title{
Mechanical Properties of High Viscosity Glass Ionomer and Glass Hybrid Restorative Materials
}

\section{Mehanička svojstva visoko viskoznog stakleno ionomera $i$ staklo hibridnog restaurativnog materijala}

\author{
$6^{\text {th }}$ year students, School of Dental Medicine, University of Zagreb, Zagreb, Croatia \\ Studenti 6. godine Stomatološkog fakulteta Sveučilišta u Zagrebu, Zagreb, Hrvatska \\ 2 Department of Materials, Faculty of Mechanical Engineering and Naval Architecture, University of Zagreb, Zagreb, Croatia \\ Zavod za materijale Fakulteta strojarstva i brodogradnje Sveučilišta u Zagrebu, Zagreb, Hrvatska \\ ${ }^{3}$ Department of Pedodontics, School of Dental Medicine, University of Zagreb, Zagreb, Croatia \\ Zavod za dječju i preventivnu stomatologiju Stomatološkog fakulteta Sveučilišta u Zagrebu, Zagreb, Hrvatska \\ ${ }^{4}$ Department of Endodontics and Restorative Dentistry, School of Dentistry, University of Zagreb, Zagreb, Croatia \\ Zavod za endodonciju i restaurativnu stomatologiju Stomatološkog fakulteta Sveučilišta u Zagrebu, Zagreb, Hrvatska
}

Abstract

Objectives: to determine the mechanical properties of hybrid and high-viscosity glass ionomer cements. Compressive strength and hardness of three glass ionomer cements (GIC) were measured: Ketac TM Universal Aplicap TM, EQUIA Fil@ and EQUIA FORTE Fil@, and the SEM sample analysis were performed. Material and Methods: The samples for measuring the compressive strength were prepared using silicone molds with standard dimensions of $6 \mathrm{~mm} \times 4 \mathrm{~mm}$ and stored in deionized water for five days, while the samples for hardness measurement were prepared using Teflon molds with a cylindrical opening in the middle, dimensions $2 \mathrm{~mm}$ in height and $5 \mathrm{~mm}$ in width. For each material, one sample was made $(n=1)$ and stored in deionized water at $37^{\circ} \mathrm{C}$ for 25 days. A representative sample of each material was analyzed using SEM. For the comparison of obtained values, the ANOVA test was used, while Tukey test was used for the multiple comparison. Results: There were no significant differences between the compressive strength of the three tested materials $(p<0.05)$. The hardness values were: 157 HV0,2 for Ketac TM Universal Aplicap TM , 47 HV0,2 for EQUIA Fil $ß$ and 39 HV0,2 for EQUIA FORTE Fil $₫$, respectively, and were significantly different, implying that Ketac ${ }^{\mathrm{T} M}$ Universal Aplicap TM has much higher hardness values than the other materials tested. SEM sample analysis revealed similar fracture modes of the tested materials. Conclusion: It was concluded that there were no statistically significant differences in compressive strength and fracture modes between the tested materials, while Ketac TM Universal Aplicap TM hardness results were significantly higher than the ones measured for EQUIA Fil ${ }^{\circ}$ and EQUIA FORTE Fil ${ }^{\circ}$.
Received: February 25, 2019

Accepted: May 15, 2019

Address for correspondence Valentina Brzović Rajić University of Zagreb

School of Dental Medicine

Department of Endodontics and Restorative Dental Medicine Gundulićeva 5, 10000 Zagreb, Croatia vbrzovic.rajic@sfzg.hr

Key words

Glass Ionomer Cement; Compressive Strength; Hardness; SEM.

\section{Introduction}

The ideal in developing new restorative materials in dental medicine is achieving appropriate biological, mechanical and esthetic properties. Glass ionomer cements (GIC) were introduced into dental practice during the 1970s of the last century (1). The GICs are made of powder and liquid; the powder consists of calcium-aluminum fluorosilicate glass and the liquid is $35-65 \%$ polyacrylic acid (2). The improvements of physical-mechanical properties over the past decades have resulted in their application in various areas: restorative dentistry, pediatric dentistry, endodontic surgery, postendodontic tooth restoration, atraumatic restorative treatment (ART) and dental prosthetics $(3-6)$.

The GICs are bioactive materials. They have the ability to release fluoride (7), which is believed to enhance the remineralization of hard tooth tissue and prevent secondary car-

\section{Uvod}

Ideal kojemu se oduvijek težilo u proizvodnji novih restaurativnih materijala u dentalnoj medicini bio je spoj zadovoljavajućih bioloških, mehaničkih i estetskih svojstava. Novo poglavlje u njihovu zbližavanju otvoreno je uvođenjem u primjenu staklenoionomernih cemenata (SIC-ova) tijekom 70-ih godina prošlog stoljeća (1). Sastav SIC-ova su prah i tekućina - prah se sastoji od kalcijsko-aluminijskog-fluorosilikatnog stakla, a tekućina je od 35 do $65 \%$ vodena otopina poliakrilne kiseline (2). Poboljšanja kvalitete svojstava u proteklim desetljećima rezultirala su primjenom SIC-ova u raznim područjima - u restaurativnoj dentalnoj medicini, dječjoj stomatologiji, endodontskoj kirurgiji, postendodontskoj opskrbi zuba, netraumatskim restaurativnim postupcima (ART - engl. atraumatic restorative treatment) te u stomatološkoj protetici $(3-6)$. 
ies. The degree of fluoride release is furthermore influenced by the composition and storing methods of the material (8). For instance, incorporation of Nano-sized particles can further enhance the fluoride release (9).

Because of their chemical composition, they connect directly with the enamel and the dentin by achieving a chemical bond with hard tooth tissue. There are many different types of GICs; the basic ones are conventional, light-curing and hybrid glass ionomer cements. Conventional GICs are divided into high-viscosity and low-viscosity GICs according to the proportion of powder and liquid part and the amount of $\mathrm{Ca}^{+}$and $\mathrm{Al}^{3+}$ ions. Hybrid materials based on GIC technology have been modified with glass particles of different sizes. This feature significantly affects physical and mechanical properties of the material (10). Furthermore, it is considered that by applying a Nano-protective coating (micro-laminated technique), the properties of the material improve (11). Hybrid (EQUIA FORTE Fil ${ }^{\circ}$ ) and high-viscosity (EQUIA Fil $\left.{ }^{\circ}\right)$ materials are clinically applied for permanent restorations by micro-laminated technique. Ketac ${ }^{\text {TM }}$ Universal Aplicap ${ }^{\text {TM }}$ is a high-viscosity GIC not combined with coating agent. Mechanical properties of GIC materials are usually estimated by compressive strength and hardness measurements, and are associated with the microstructure of the material (12). Various techniques may be used to analyze the material structure. The scanning electron microscopy (SEM) proved to be the most acceptable procedure for inspecting the surface of materials, particle size and porosity (13); these elements give significant insight into the properties of GICs and are, therefore, suitable for this study (14).

The aim of this research was to determine the mechanical properties of two types of materials: hybrid and high-viscosity glass ionomeric cements. The zero hypothesis was that there would be no differences in compressive strength, hardness and fracture modes between the tested materials

\section{Materials and methods}

\section{Examined materials and preparation of specimens}

The materials used in this study are listed in Table 1. The materials belong to the group of encapsulated GIC systems; hence each capsule was prepared in the mixer $3 \mathrm{M}^{\mathrm{Tm}} \mathrm{ESPE}^{\mathrm{TM}}$ CapMix $^{\mathrm{TM}}$ (3M ESPE, Seefeld, Germany) for eight seconds, according to the manufacturer's instructions.

EQUIA $\mathrm{Fil}^{\circ}$ and EQUIA FORTE $\mathrm{Fil}^{\circ}$ belong to the group of micro-laminated GICs, while Ketac ${ }^{\mathrm{TM}}$ Universal Aplicap ${ }^{\mathrm{TM}}$ is regarded as a conventional high-viscosity material. Micro-laminated GICs are materials of newer generation with improved properties and, according to manufacturers, the first GICs that can be used to create durable fillings in posterior region (15). No protective coating was used during sample testing and the specimens were not lit by a polymerization lamp. Sample dimensions and method of preparation
SIC-ovi su bioaktivni materijali sa svojstvom otpuštanja fluorida (7) zbog čega, kako se smatra, pospješuju remineralizaciju tvrdih zubnih tkiva i djeluju karijesno protektivno. Sol fluorida disocira, a zatim se fluor otpušta iz materijala difundirajući kroz cement (8). Stupanj oslobađanja fluorida pod utjecajem je sastava i načina skladištenja materijala (9). Primjerice, ugradnjom čestica nano veličine dodatno se pojačava otpuštanje fluora (10). Zbog kemijskog sastava vezuju se izravno na caklinu i dentin, ostvarujući kemijsku vezu s tvrdim zubnim tkivom. Postoje različite podjele SIC-ova - najjednostavnija je na konvencionalne, svjetlosno polimerizirajuće i hibridne staklenoionomerne cemente. Konvencionalni SIC-ovi razlikuju se prema udjelu praška i tekućeg dijela te količini iona $\mathrm{Ca}^{+} \mathrm{i} \mathrm{Al}^{3+}$. Prema tom se kriteriju konvencionalni SIC-ovi mogu podijeliti na visokoviskozne i niskoviskozne. Hibridni materijali temeljeni na SIC tehnologiji modificirani su staklenim česticama različitih veličina. To, prema podatcima proizvođača, znatno utječe na fizičko-mehanička svojstva materijala (11). Nadalje, smatra se da se uvođenjem nano zaštitnog premaza (mikrolaminirana tehnika) koji se ugrađuje u materijal dodatno pojačavaju njegova svojstva (12). Staklohibridni (EQUIA FORTE Fil ${ }^{\circ}$ ) i visokoviskozni materijal (EQUIA Fil ${ }^{\circ}$ ) klinički se primjenjuju za trajne restauracije mikrolaminiranom tehnikom. "Ketac Univesal Aplicap" također je visokoviskozni SIC, ali bez premaza.

Usporedba kvalitete pojedinih vrsta SIC-ova temelji se na različitosti njihovih mehaničkih svojstava, posebno tlačne čvrstoće i tvrdoće. Navedena mehanička svojstva povezana su s mikrostrukturom materijala (13). Za analizu strukture materijala mogu se primijeniti razne tehnike. Pregledna elektronska mikroskopija (engl. Scanning electron microscopy - SEM) pokazala se najprihvatljivijom za ispitivanje svojstava površine materijala, veličine čestica i poroznosti (14). Navedeni elementi daju važan uvid u svojstva GIC-a te su zato prikladni za ovo istraživanje.

Cilj ovog istraživanja bio je odrediti mehanička svojstva dviju vrsta materijala - hibridnih i visokoviskoznih staklenoionomernih cemenata. Zadane nulte hipoteze glasile su da neće biti razlike u tlačnoj čvrstoći, tvrdoći te strukturi ispitivanih materijala.

\section{Materijali i metode}

\section{Ispitivani materijali i priprema uzoraka}

U ovom istraživanju upotrijebljena su tri SIC-a navedena u tablici 1. Pripadaju skupini inkapsuliranih SIC sustava zato što je svaka kapsula pri pripremi stavljena osam sekunda u miješalicu $3 \mathrm{M}^{\mathrm{TM}} \mathrm{ESPE}^{\mathrm{TM}}$ CapMix ${ }^{\mathrm{TM}}$ (3M ESPE, Seefeld, Njemačka), prema uputi proizvođača. Staklenoionomerni cementi EQUIA Fil" i EQUIA FORTE Fil" uvršteni su u skupinu mikrolaminiranih SIC-ova, a Ketac ${ }^{\text {TM }}$ Universal Aplicap $^{\text {Tm }}$ u konvencionalne visokoviskozne materijale. Mikrolaminirani SIC-ovi novija su generacija materijala s poboljšanim svojstvima te su, prema podatcima proizvođača, prvi koji se mogu koristiti za izradu trajnih ispuna u stražnjoj regiji (15). Pri izradi uzoraka za ispitivanje nije korišten zaštitni premaz i uzorci nisu bili tretirani svjetiljkom za polimerizaciju. Dimenzije uzoraka i način pripreme za ispitivanje obaju svoj- 
Table 1 The results of compressive strength and hardness of tested materials

Tablica 1. Rezultati tlačne čvrstoće i tvrdoće ispitivanih materijala

\begin{tabular}{|c|c|c|c|c|c|c|c|}
\hline & \multicolumn{2}{|c|}{ EQUIA Fil } & \multicolumn{2}{|c|}{ EQUIA FORTE Fil } & \multicolumn{2}{|c|}{ Ketac $^{\mathrm{TM}}$ Universal Aplicap ${ }^{\mathrm{TM}}$} & \multirow{2}{*}{$\begin{array}{c}\text { ANOVA } \\
\text { p }\end{array}$} \\
\hline & $\begin{array}{l}\text { Average • } \\
\text { Prosjek }\end{array}$ & st.d. & $\begin{array}{l}\text { Average • } \\
\text { Prosjek }\end{array}$ & st.d. & $\begin{array}{l}\text { Average • } \\
\text { Prosjek }\end{array}$ & st.d. & \\
\hline $\begin{array}{l}\text { Maximum force }(\mathrm{N}) \bullet \\
\text { Maksimalna sila }(\mathrm{N})\end{array}$ & 1259.7 & $(635.9)$ & 1277.3 & $(695.2)$ & 1046.4 & $(519.2)$ & 0.66 \\
\hline $\begin{array}{l}\text { Compressive strength }\left(\mathrm{N} / \mathrm{mm}^{2}\right) \bullet \\
\text { Tlačna čvrstoća }\left(\mathrm{N} / \mathrm{mm}^{2}\right)\end{array}$ & 97.6 & $(49.1)$ & 99.6 & $(53.6)$ & 80.0 & $(38.7)$ & 0.60 \\
\hline
\end{tabular}

for testing both properties were made according to other relevant studies $(16,17)$. One measurement for each sample was performed by an independent researcher at the Department of Materials at the Faculty of Mechanical Engineering and Naval Architecture of the University of Zagreb.

Compressive strength test specimens were prepared using a silicone mold with standard dimensions of $6 \mathrm{~mm} \mathrm{x} 4 \mathrm{~mm}$. The mold was placed on a glass tile and filled with material immediately after capsule mixing and covered with the acetate foil. Lightweight pressure was applied to the surface of the foil to prevent bubble formation and to achieve smooth surface (18). After three minutes, foil, tile and excess material were removed, and the specimen was then polished with standard metallographic grinding paper (P1000, Pace Technologies, and Tucson, USA) and stored in deionized water for five days at $37^{\circ} \mathrm{C}$ water temperature.

For the determination of hardness of the materials, specimens were prepared using Teflon molds with a cylindrical opening in the middle, dimensions $2 \mathrm{~mm}$ in height and 5 $\mathrm{mm}$ in width. For each material, one sample was made $(\mathrm{n}=$ 1). The molds were placed on glass tile covered with acetate foil and filled with the tested GIC. The mold was then covered with acetate foil on the other side and put under light pressure by using a glass tile. After curing for 3 minutes, glass tiles, acetate foil and excess material were removed and the specimens were stored in deionized water for 25 days at $37^{\circ}$ C water temperature.

SEM analysis was used for one specimen of each test material $(\mathrm{n}=1)$. The specimens were prepared in Teflon molds with a cylindrical opening in the middle, dimension $2 \mathrm{~mm}$ in height and $5 \mathrm{~mm}$ in width. After curing for three minutes, the specimens were ground and polished. They were ground with standard metallographic grinding paper, Pace Technologies, Tucson, USA, from rough to finer - P320, P500, P1000, P2400, and P4000 - with water cooling. The speed was 300 revolutions per minute and the pressure force was equal to the manual force. The specimens were polished with diamond pasta $3 \mathrm{um}$ and $1 \mathrm{um}$ in two steps at a speed of 150 $\mathrm{rpm}$ and a force of $30 \mathrm{~N}$ pressure. Prior to analysis, all specimens were cooled and lubricated.

Determination of compressive strength, hardness and SEM analysis

The compressive strength was measured in a VEB device (WPM Werkstoffprüfsysteme Leipzig GmbH, Markkleeberg, stava rađeni su prema drugim relevantnim ispitivanjima (16, 17). Po jedno mjerenje za svaki uzorak obavio je neovisni ispitivač u Zavodu za materijale Fakulteta strojarstva i brodogradnje Sveučilišta u Zagrebu.

Uzorci za ispitivanje tlačne čvrstoće pripremljeni su s pomoću silikonskog kalupa standardnih dimenzija $-6 \mathrm{~mm}$ u visinu i $4 \mathrm{~mm}$ u širinu. Kalupi su bili postavljeni na staklenu pločicu te se u njih, neposredno nakon miješanja, aplicirao sadržaj kapsule u suvišku i prekrio acetatnom folijom, čijom se primjenom postiže najmanja hrapavost površine SIC-a (18). Na površinu folije primijenjen je lagani pritisak kako bi se spriječilo stvaranje mjehurića te postigla ravna i glatka površina. Nakon tri minute uklonjeni su folija, pločica i višak materijala, a uzorak je ispoliran brusnim papirom (Standard metallographic grinding paper, P1000, Pace Technologies, Tucson, $\mathrm{SAD}$ ) i pohranjen pet dana u deioniziranu vodu temperature $37^{\circ} \mathrm{C}$.

Za određivanje tvrdoće materijala koristili su se uzorci pripremljeni s pomoću namjenski izrađenih teflonskih kalupa s cilindričnim otvorom u sredini, dimenzija $2 \mathrm{~mm}$ u visinu i $5 \mathrm{~mm}$ u širinu. Za svaki je materijal izrađen po jedan uzorak $(n=1)$. Kalupi su postavljeni na staklene pločice na koje je prije toga položena acetatna folija i u njih je apliciran ispitivani SIC. Nakon toga kalup je is druge strane prekriven acetatnom folijom na koju je zatim primijenjen lagani pritisak staklenom pločicom. Nakon trominutnog stvrdnjavanja uklonjene su staklene pločice, acetatne folije i višak materijala, a uzorak je pohranjen na 25 dana u deioniziranu vodu na temperaturi od $37^{\circ} \mathrm{C}$.

Za SEM analizu upotrijebljen je po jedan uzorak od svakog ispitivanog materijala $(\mathrm{n}=1)$.

Uzorci su pripremani u teflonskim kalupima s cilindričnim otvorom u sredini dimenzija $2 \mathrm{~mm}$ u visinu i $5 \mathrm{~mm}$ u širinu. Nakon trominutnog stvrdnjavanja uzorci su brušeni i polirani. Brusilo se brusnim papirom (Standard metallographic grinding paper, Pace Technologies, Tucson, SAD) od grubljega prema finijem - P320, P500, P1000, P2400, P4000 - uz vodeno hlađenje. Brzina okretaja iznosila je 300 okretaja u minuti, a sila pritiska bila je jednaka ručnoj sili. Uzorci su polirani dijamantnim pastama 3um i lum u dva koraka, pri brzini od 150 okretaja u minuti i sili pritiska od 30 N. Neposredno prije analize svi su uzorci ohlađeni i podmazani.

\section{Određivanje tlačne čvrstoće, tvrdoće te SEM analiza}

Tlačna čvrstoća mjerila se u uređaju VEB (WPM Werkstoffprüfsysteme Leipzig GmbH, Markkleeberg, Njemačka; EU 40 mod; ser.br. /83/35) na temperaturi od $24,5^{\circ} \mathrm{C}$ i brzi- 
Germany; EU 40 mod., Serial number 83/35) at a temperature of $24.5^{\circ} \mathrm{C}$ with a load speed of $20 \mathrm{~N} /$ sec. 10 specimens of each material were prepared $(n=10)$. The average dimensions of the specimens used to determine the compressive strength are approximately $6 \mathrm{~mm}$ in height and $4 \mathrm{~mm}$ in width (ISO Standard ISO9917-1). Prior to placing the specimens in the testing machine, their dimensions were measured by a micrometer with a precision of $0.01 \mathrm{~mm}$. The compressive strength $(\mathrm{RH})$ was calculated according to the formula

$$
\mathrm{RH}=\frac{\mathrm{FH}}{\mathrm{s}_{0}}, \mathrm{~S}_{0}=\frac{d_{0}^{2} \pi}{\mathbf{4}},
$$

where $\mathrm{FH}$ is the maximum force due to the sample fracture, S0 the cross-sectional area of the sample, and $\mathrm{d}$ the width of the sample.

Hardness was measured using PMT-3 device (OKB Spectr, Sankt-Peterburg, Russia). A Vickers method with a load of $0.2 \times 9.81 \mathrm{~N}$ was used, which corresponds to the HV0,2 method.

The Vega electron microscope (Tescan, Brno, Czech Republic) was used to determine the microstructure of each tested specimen.

\section{Statistical Analysis}

ANOVA test, usually used to analyze the differences among group means in a sample, was used to compare the value of the different types of filling, while the Tukey's test was used for multiple comparisons. The analysis was made using the SAS statistical package, a software application for statistical analysis, on the Windows platform. All the tests were performed with level of significance $\alpha=0.05$.

\section{Results}

The results of the compressive strength and hardness measurements are shown in Table 1. Maximum Force (FH) was used to calculate the compressive strength. The difference in compressive strength between the tested materials was not statistically significant. On the other hand, Ketac ${ }^{\mathrm{TM}}$ Univer- ni porasta opterećenja od $20 \mathrm{~N} / \mathrm{s}$. Od svakog materijala izrađeno je 10 uzoraka $(n=10)$. Prosječne dimenzije uzoraka korištenih za određivanje tlačne čvrstoće približno su iznosile 6 $\mathrm{mm}$ u visinu i $4 \mathrm{~mm}$ u širinu (standard ISO 9917-1). Neposredno prije postavljanja uzoraka u kidalicu, njihove su dimenzije izmjerene mikrometrom s preciznošću od $0,01 \mathrm{~mm}$. Tlačna čvrstoća $(\mathrm{RH})$ izračunata je prema formuli

$$
\mathrm{RH}=\frac{\mathrm{FH}}{\mathrm{S}_{0}}, \mathrm{~S}_{0}=\frac{d_{0}^{2} \pi}{\mathbf{4}},
$$

u kojoj je FH maksimalna sila zbog koje se dogodilo lomljenje uzorka, $S_{0}$ površina poprečnog presjeka uzorka, a d širina uzorka.

Tvrdoća je mjerena uređajem PMT-3 (OKB Spectr, Sankt-Peterburg, Rusija). Korištena je Vickersova metoda s opterećenjem od 0,2 x 9,81 N, što odgovara metodi HV0,2.

Preglednim elektronskim mikroskopom Vega (Tescan, Brno, Ceška) utvrdila se mikrostruktura svakog ispitivanog uzorka.

\section{Statistička obrada podataka}

Za usporedbu vrijednosti obilježja između različitih vrsta ispuna korištena je ANOVA, najčešća parametrijska statistička metoda za testiranje hipoteza, a za višestruku usporedbu Tukeyev test. Analiza je obavljena u softveru za statističku analizu SAS na Windowsovoj platformi. Svi su testovi radeni uz razinu značajnosti $\alpha=0,05$.

\section{Rezultati}

Rezultati ispitivanja tlačne čvrstoće i tvrdoće ispitivanih materijala prikazani su u tablici 1. Maksimalna sila (engl. high force - FH) rabila se za izračunavanje tlačne čvrstoće. Rezultati upućuju na to da nema značajnije razlike u tlačnoj čvrstoći između ispitivanih materijala. $S$ druge strane, dobi-
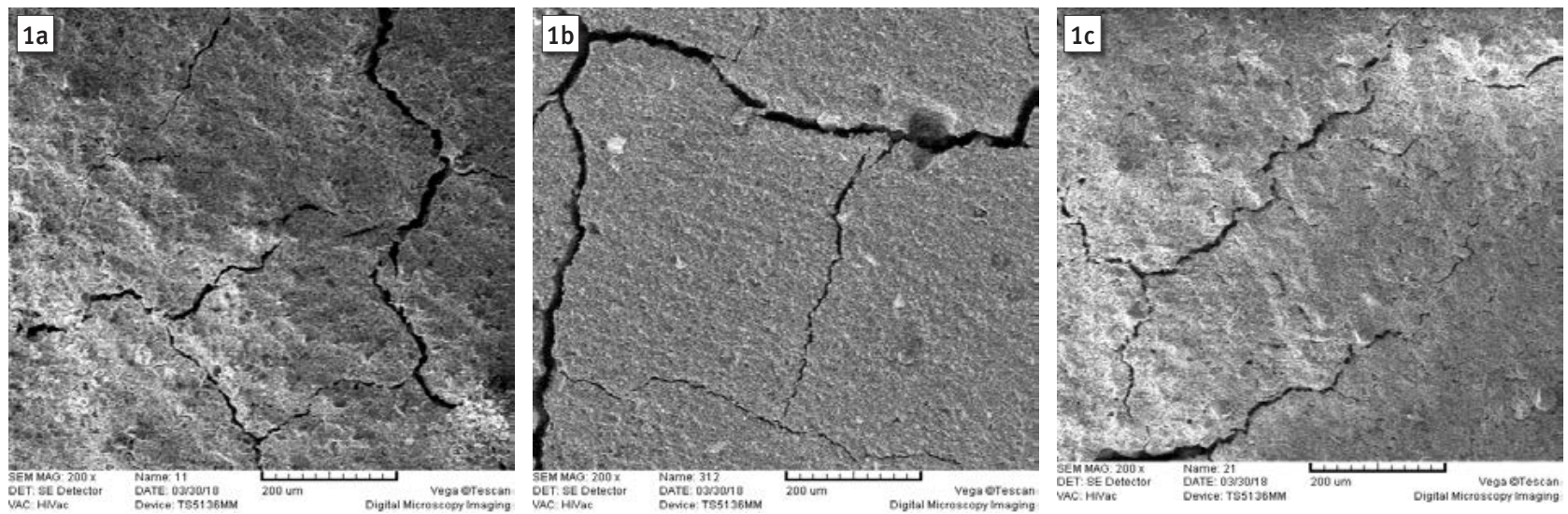

Figure 1a SEM image of Ketac TM Universal Aplicap TM GIC sample surface (200x)

Slika 1. a SEM prikaz površine uzorka Ketac TM Universal Aplicap TM SIC-a (200 x)

Figure 1b SEM image of Equia FORTE Fil ${ }^{\circledR}$ GIC sample surface (200x)

Slika 1. b SEM prikaz površine uzorka Equia FORTE Fil ${ }^{\circledR}$ SIC-a $(200$ x)

Figure 1C SEM image of Equia Fil ${ }^{\circledR}$ GIC sample surface (200x)

Slika 1. c SEM prikaz površine uzorka Equia Fil ${ }^{\circledR}$ SIC-a $(200 \mathrm{x})$ 
sal Aplicap ${ }^{\mathrm{TM}}$ hardness values were significantly higher than the ones measured for EQUIA Fil ${ }^{\circ}$ and EQUIA FORTE Fil ${ }^{\circ}$ GIC.

The SEM analysis of the structure showed similar cohesive cracks in all tested specimens. (Figures $1 \mathrm{a}, 1 \mathrm{~b}$ and $1 \mathrm{c}$ ), showing the need for further material improvements.

\section{Discussion}

It is believed that the information about compressive strength and hardness of the material can give insight into their mechanical integrity. Moreover, the compressive strength results are often used to estimate the durability of the material when exposed to masticatory forces (19). Although it might be very interesting from clinical perspective to compare the values exhibited by the materials in our research with other restorative materials, it is very hard to do so because of different experimental settings. The obtained results showed that there was no statistically significant difference in the compressive strength of the tested materials, thus the first null hypothesis was confirmed.

Specimens of standard dimensions of $6 \mathrm{~mm} \times 4 \mathrm{~mm}$ according to ISO 9917-1 were used in this study. There are other standardized systems such as ANSI / ADA Specification No. 66, which prepare specimens of larger dimensions. Mallman et al. (16) have demonstrated that specimens with larger dimensions exhibit better mechanical properties. However, larger size specimens have the potential for creating irregular structures (16). For this reason, in this study, smaller specimens were used to ensure a good material structure. The mixing behavior affects the structure of the material. The examined materials come into the market in capsulated form. Such packaging, apart from facilitating clinical use, reduces the possibility of mistakes when mixing the material. In this study the compressive strength of capsulated GIC was tested, which according to the manufacturer can be used for definite restorations. The storage time of the specimens was five days, due to the fact that immediately after mixing GICs have weak mechanical properties until they mature (20). In this study, lower compressive strength values were obtained compared to the manufacturer's claims $(21,22)$. A possible explanation for the obtained values was that the specimens were stored in deionized water and that ions were released into the fluid possibly leading to lower values for all the tested materials (23). The influence of early water uptake on GIC materials tends to be reduced by applying protective coatings. Despite the manufacturer's recommendation for Equia Fill ${ }^{\circ}$ and Equia FORTE Fil ${ }^{\circ}$, the materials were tested without application of protective coating, which could have also lead to the results which are inferior to those obtained by the manufacturer (24). The results of this study have shown that Ketac ${ }^{\text {TM }}$ Universal Aplicap ${ }^{\mathrm{TM}}$ has higher hardness values compared to EQUIA Fil ${ }^{{ }^{\circ}}$ and EQUIA Forte Fil ${ }^{\bullet}$, therefore the second null hypothesis that there is no difference in hardness between hybrid and highviscosity GICs has been rejected.

Brinell, Rockwell, Shore, Vickers and Knoop test methods (25) can be used to measure the hardness of dental mate- vene vrijednosti tvrdoće za materijal Ketac ${ }^{\mathrm{TM}}$ Universal Apli$\mathrm{cap}^{\mathrm{TM}}$ znatno su veće od izmjerenih za materijale EQUIA Fil ${ }^{\circ}$ i EQUIA FORTE Fil ${ }^{\circ}$. SEM analiza strukture pokazala je kohezivne pukotine u svim ispitivanim uzorcima (slike 1. a, 1 . b i 1. c), što pokazuje potrebu za daljnjim poboljšanjem materijala.

\section{Rasprava}

Smatra se da podatci o tlačnoj čvrstoći i tvrdoći materijala daju informacije o njihovu mehaničkom integritetu. Štoviše, vrijednosti tlačne čvrstoće često se koriste za procjenu izdržljivosti materijala pri izloženosti žvačnim silama (19). Iako bi iz kliničke perspektive bilo zanimljivo usporediti rezultate ovoga rada s onima za druge restaurativne materijale, to je teško učiniti zbog različitih uvjeta u pojedinim istraživanjima. Dobiveni rezultati pokazali su da nema statistički značajne razlike u tlačnoj čvrstoći ispitivanih materijala, čime je potvrđena prva nulta hipoteza o nepostojanju razlike u tlačnoj čvrstoći između hibridnih i visokoviskoznih SIC-ova.

$\mathrm{U}$ ovom ispitivanju korišteni su uzorci standardnih dimenzija $6 \mathrm{~mm}$ x $4 \mathrm{~mm}$ prema standardu ISO 9917-1. Postoje i drugi standardizirani sustavi kao što je ANSI/ADA specifikacija broj 66, prema kojoj se pripremaju uzorci većih dimenzija. Mallman i suradnici (16) dokazali su da uzorci većih dimenzija pokazuju bolja mehanička svojstva. No u uzorcima većih dimenzija postoji veća mogućnost za stvaranje nepravilne strukture (16). Upravo su se zato u ovom istraživanju upotrijebili manji uzorci kako bi se osigurala dobra struktura materijala. Na strukturu materijala utječe i način miješanja. Ispitivani materijali dolaze na tržište u kapsuliranom obliku. Takav način pakiranja, uz to što olakšava kliničku primjenu, smanjuje mogućnost pogreške pri miješanju materijala te se u ovom radu ispitivala tlačna čvrstoća kapsuliranih SIC-ova koji se, prema proizvođaču, primjenjuju za konačne ispune. Vrijeme pohrane uzoraka u ovom je istraživanju bilo pet dana jer SIC-ovi neposredno nakon miješanja imaju slabija mehanička svojstva sve dok ne maturiraju (20). U ovom radu dobivene su manje vrijednosti čvrstoće u usporedbi s tvrdnjama proizvođača $(21,22)$. Moguće objašnjenje za to jest da su uzorci bili pohranjeni u deioniziranoj vodi i da su se u tekućinu oslobodili ioni, pa su tako dobivene neizravno manje vrijednosti za sve ispitivane materijale (23). Utjecaj vode na SIC-ove nastoji se smanjiti primjenom zaštitnih premaza koji bitno utječu na tvrdoću materijala, drugo ispitivano svojstvo u ovom radu. Unatoč preporuci 16 proizvođača za materijale Equia Fill ${ }^{\circ}$ i Equia FORTE Fil ${ }^{\circ}$, svojstva su ispitivana bez primjene zaštitnog premaza, što je također utjecalo na slabije rezultate u usporedbi s podatcima proizvođača (24). Rezultati ovog istraživanja pokazali su da Ketac ${ }^{\text {TM }}$ Universal Aplicap $^{\text {TM }}$ ima veću vrijednost tvrdoće u odnosu prema EQUIA Filu ${ }^{\circ} \mathrm{i}$ EQUIA Forte Filu ${ }^{\circ}$, a takvim je rezultatom odbačena druga nulta hipoteza o nepostojanju razlike u tvrdoći između hibridnih i visokoviskoznih SIC-ova.

$\mathrm{Za}$ mjerenje tvrdoće dentalnih materijala mogu se koristiti metode prema Brinellu, Rockwellu, Shoreu, Vickersu i Knoopu (25). Iako je u većini drugih radova korištena metoda prema Knoppu, zbog dostupnosti opreme u ovom je ra- 
rials. Although the Knoop's method is most commonly used method, due to availability of equipment, the Vickers test method was used in this study, which was also used in other relevant studies $(26,27)$. It is interesting that both bulk fill systems, EQUIA Fil ${ }^{\circ}$ and EQUIA FORTE Fil ${ }^{\circ}$, had lower hardness values. Therefore, it can be concluded that the application of protective coating on these materials is mandatory in order to achieve the hardness comparable to other GIC materials (28). The manufacturer recommends a Nano punctured light-curing resin-based coating. It is stated that the coating, due to its low viscosity, fills the micro-gaps in the GICs structure. In this way, the improved surface better tolerates the impact of the masticatory forces and protects against erosion (29). Furthermore, the manufacturer claims that this protective coating reduces the wear of GIC when used in restorations in posterior region (29).

The influence of all the forces acting on the specimens reflects on their microstructure and fracture modes. SEM analysis showed cohesive cracks in all examined specimens which is in accordance with data from the literature (30). This may be due to the dehydration of the specimens which is necessary in preparations for SEM analysis (9). Thus, the third null hypothesis that there was no difference in the fracture modes of hybrid and high-viscosity materials was accepted. Despite the continuous development of the materials and the improvement of their properties, imperfections such as cohesive fractures are yet to be eliminated. This fact is confirmed by this research, using the newest materials on the market. That is a clinically important feature because it shows that the material and tooth bond is stable, and in a minimally invasive concept of restoration it is more important that, if a fracture occurs, the restorative material is affected, not the tooth.

As this is an in vitro study, the oral conditions could not be completely simulated. However, all the samples were exposed to the same experimental conditions. Within the limitations of this study, a good insight into material endurance was given, but the absolute values of the mechanical properties recorded must be interpreted with respect to the experimental conditions.

\section{Conclusion}

There was no significant difference in compressive strength between the tested materials. The hardness values were significantly higher for $\mathrm{Ketac}^{\mathrm{TM}}$ Universal Aplicap ${ }^{\mathrm{Tm}}$ compared with EQUIA Fil and EQUIA FORTE Fil materials, which probably came as a result of not using the recommended protective coating when preparing the EQUIA Fil $^{\circ}$ and EQUIA FORTE Fil samples. SEM analysis showed similar microstructure and fracture modes of the three tested materials, justifying their use in in a minimally invasive concept of restoration.

\section{Acknowledgements}

The research was conducted within the Croatian Foundation for Research and Development of New Micro and Nanostructural Bioactive Materials in Dental Medicine BIODENTMED No. IP-2018-01-1719." du odabrana Vickersova metoda kojom su se, kako se ističe u literaturi, postigli relevantni rezultati $(26,27)$. Zanimljivo je da su rezultati pokazali da oba materijala bulk fill sustava - EQUIA Fil ${ }^{\circ}$ i EQUIA FORTE Fil ${ }^{\circ}$ - imaju slabiju tvrdoću. Iz toga se može zaključiti da je pri primjeni navedenih materijala obvezatan zaštitni premaz, kako bi se postigla tvrdoća usporediva s ostalima (28). Proizvođač preporučuje nanopunjeni svjetlosno polimerizirajući zaštitni premaz na temelju smole. Navodi se da premaz zbog niske viskoznosti popunjava mikropukotine u strukturi SIC-ova, a tako poboljšana površina bolje podnosi utjecaj žvačnih sila i zaštićena je od erozija (29). Nadalje, proizvođač tvrdi da taj zaštitni premaz smanjuje trošenje SIC-iva kada se koriste za restauracije na stražnjim zubima (29).

Utjecaj svih sila kojima se djeluje na uzorke pri određivanju njihovih svojstava izvrsno se prikazuje učinkom na mikrostrukturu te vrstom pukotina. SEM analiza strukture pokazala je kohezivne pukotine u svim ispitivanim uzorcima, $\mathrm{u}$ skladu s podatcima iz literature (30) u kojima se tvrdi da SICovi uvijek pucaju kohezivno, a ne adhezivno. Time je potvrdena treća nulta hipoteza da nema razlike u strukturi materijala između hibridnih i visokoviskoznih materijala. Možda se zbog toga i događa dehidracija uzoraka koja je prijeko potrebna u pripremi za SEM analizu (9). Unatoč neprekidnom razvoju materijala i poboljšanju njihovih svojstava, nedostatci poput (17) kohezivnog pucanja još nisu otklonjeni. To pokazuju i rezultati SEM analize u ovom radu u kojemu su korišteni najnoviji materijali na tržištu. Klinički je to svojstvo važno jer je spoj materijala i zuba stabilan, a u minimalno invazivnom konceptu restauracije važnije je da, ako se dogodi lom, pukne materijal, a ne zub.

Budući da je ovo istraživanje in vitro, uvjete usne šupljine nije bilo moguće potpuno reproducirati. No, svi su uzorci bili izloženi jednakim utjecajima. Prema uvjetima u ovom istraživanja dobio se dobar uvid u izdržljivost materijala, ali sve zabilježene vrijednosti mehaničkih svojstava moraju se promatrati unutar eksperimentalnih uvjeta.

\section{Zaključak}

U opisanim uvjetima ovoga rada nisu pronađene značajnije razlike u tlačnoj čvrstoći ispitivanih materijala. Vrijednosti tvrdoće bile su znatno više za Ketac ${ }^{\mathrm{TM}}$ Universal Aplicap ${ }^{\mathrm{T} M} \mathrm{u}$ usporedbi $s$ materijalima EQUIA Fil ${ }^{\circ}$ i EQUIA FORTE Fil', što je vjerojatno rezultat nekorištenja preporučenog zaštitnog premaza tijekom pripreme EQUIA Fila i EQUIA FORTE Filå. SEM analiza pokazala je sličnu mikrostrukturu i vrste pukotina u trima ispitivanim materijalima, opravdavajući njihovu uporabu u konceptu minimalno invazivne restauracije.

\section{Zahvala}

Istraživanje je provedeno u sklopu Hrvatske zaklade za znanost - istraživačkog projekta Istraživanje i razvoj novih mikro i nanostrukturnih bioaktivnih materijala u dentalnoj medicini-BIODENTMED No. IP-2018-01-1719. 


\section{Conflict of interest}

The authors report no conflict of interest.

\section{Sukob interesa}

Autori izjavljuju da nisu bili u sukobu interesa.

\section{Sažetak}

Svrha rada: Željela su se odrediti mehanička svojstva hibridnih i visokoviskoznih staklenoionomernih cemenata. Mjerila se tlačna čvrstoća i tvrdoća triju staklenoionomernoh cemenata (SIC-ova) Ketac $^{\text {TM }}$ Universal Aplicap ${ }^{\text {TM }}$, EQUIA Fil ${ }^{\circledR}$ i EQUIA FORTE Fi $^{\circledR}$ te je obavljena SEM analiza uzoraka. Materijali i metode: Uzorci za mjerenje tlačne čvrstoće pripremljeni su s pomoću silikonskih kalupa dimenzija $6 \mathrm{~mm}$ u visinu i $4 \mathrm{~mm}$ u širinu te su pet dana bili pohranjeni u deioniziranoj vodi, a uzorci za mjerenje tvrdoće pripremljeni su s pomoću teflonskih kalupa dimenzija $2 \mathrm{~mm}$ u visinu i $5 \mathrm{~mm} \mathrm{u}$ širinu i zatim pohranjeni 25 dana u vodi na temperaturi od 37 stupnjeva. Reprezentativni uzorak svakog materijala podvrgnut je SEM mikroskopiji. Za usporedbu dobivenih vrijednosti korišten je ANOVA-test, a za višestruku usporedbu Tukeyev test. Rezultati: Nema značajnije razlike između tlačne čvrstoće triju ispitivanih materijala $(p<0,05)$, a dobivene vrijednosti tvrdoće iznosile su: Ketac ${ }^{\top M}$ Universal Aplicap ${ }^{\mathrm{TM}}$ - 157 HV0,2, EQUIA Fil ${ }^{\circledR}-47$ HVO,2 i EQUIA FORTE Fil ${ }^{\circledR}-39$ HV0,2. Zaključak: Promatrajući dobivene rezultate tvrdoće uočavaju se značajno veće vrijednosti za materijal Ketac ${ }^{\mathrm{TM}}$ Universal Aplicap ${ }^{\mathrm{TM}}$. SEM analiza uzoraka nije otkrila značajnije razlike u strukturi ispitivanih materijala EQUIA FORTE Fil ${ }^{\circledR}$, EQUIA Fil ${ }^{\circledR}$ i Ketac ${ }^{\text {TM }}$ Univesal Aplicap ${ }^{\text {TM }}$.
Zaprimljen: 25. veljače 2018 . Prihvaćen: 15. svibnja 2018.

Adresa za dopisivanje

Valentina Brzović Rajić

Sveučilište u Zagrebu Stomatološki

fakultet

Zavod za endodonciju i restaurativnu stomatologiju

Gundulićeva 5, 10000 Zagreb

tel: 4802111

vbrzovic.rajic@sfzg.hr

Ključne riječi

staklenoionomerni cement, tlačna čvrstoća, tvrdoća, SEM

\section{References}

1. Wilson $A D$, Kent BE. A new translucent cement for dentistry. The glass ionomer cement. Br Dent J. 1972 Feb 15;132(4):133-5.

2. McLean JW, Nicholson JW, Wilson AD. Proposed nomenclature for glass-ionomer dental cements and related materials. Quintessence Int. 1994 Sep;25(9):587-9.

3. Jukić Krmek S. Pretklinička endodoncija. 1st ed. Zagreb: Medicinska naklada; 2017. pp. 149-54.

4. Bonifacio et al. Physical-mechanical properties of glass ionomer cements indicated for atraumatic restorative treatment. Dent Clin North Am. 2010 Jul;54(3):551-63.

5. Ngo H. Glass-ionomer cements as restorative and preventive materials. Dent Clin North Am. 2010 Jul;54(3):551-63.

6. de Bruyne MA, De Moor RJ. The use of glass ionomer cements in both conventional and surgical endodontics. Int Endod J. 2004 Feb;37(2):91-104.

7. Forsten L. Fluoride release and uptake by glass-ionomers and related materials and its clinical effect. Biomaterials. 1998 Mar;19(6):503-8.

8. Brzović-Rajić V, Miletić I, Gurgan S, Peroš K, Verzak Ž, IvaniševićMalčić A. Fluoride Release from Glass Ionomer with Nano Filled Coat and Varnish. Acta Stomatol Croat. 2018;52(4):307-313.

9. Zafar MS, Ahmed N. Therapeutic roles of fluoride released from restorative dental materials. Fluoride. 2015;48:184-94.

10. Najeeb S, Khurshid Z, Zafar MS, Khan AS, Zohaib S, et al. Modifications in Glass lonomer Cements: Nano-Sized Fillers and Bioactive Nanoceramics. Int J Mol Sci. 2016 Jul 14;17(7).

11. De Caluwé T, Vercruysse CW, Fraeyman S, Verbeeck RM. The influence of particle size and fluorine content of aluminosilicate glass on the glass ionomer cement properties. Dent Mater. 2014 Sep;30(9):1029-38.

12. Diem VT, Tyas MJ, Ngo HC, Phuong LH, Khanh ND. The effect of a nano-filled resin coating on the 3-year clinical performance of a conventional high-viscosity glass-ionomer cement. Clin Oral Investig. $2014 \mathrm{Apr} ; 18(3): 753-9$.

13. Xie D, Brantley WA, Culbertson BM, Wang G. Mechanical properties and microstructures of glass-ionomer cements. Dent Mater. 2000 Mar;16(2):129-38.

14. Swift EJ Jr, Dogan AU. Analysis of glass ionomer cement with use of scanning electron microscopy. J Prosthet Dent. 1990 Aug;64(2):167-74.

15. Miletić I, Anić I, Bago I, Baraba A. Stakleno-ionomerni cementi. Vjesnik dentalne medicine. 2011;18(4):15-20.

16. Mallmann A, Ataíde JC, Amoedo R, Rocha PV, Jacques LB. Compressive strength of glass ionomer cements using different specimen dimensions. Braz Oral Res. 2007;21(3):204-8.

17. Roche, Kevin J. and Kenneth T. Stanton. "Improving mechanical properties of glass ionomer cements with fluorhydroxyapatite nanoparticles." (2012).
18. Miličević A, Goršeta K, van Duinen RN, Glavina D. Surface Roughness of Glass lonomer Cements after Application of Different Polishing Techniques. Acta Stomatol Croat. 2018;52(4):314-321.

19. Sukumaran V. G, Mensudar R. To Evaluate the Effect of Surface Coating on Three Different Types Glass Ionomer Restorations. Biomed Pharmacol J. 2015;8:445-49.

20. Kleverlaan CJ, van Duinen RN, Feilzer AJ. Mechanical properties of glass ionomer cements affected by curing methods. Dent Mater. 2004 Jan;20(1):45-50.

21. MeSH Browser [database on the Internet]. Ketac ${ }^{\mathrm{TM}}$ Universal Aplicap TM Glass lonomer Restorative Technical Product. [cited 2018 Apr 24] Available from: multimedia.3m.com/mws/ media/10904080/ketac-universal-aplicap-technical-product profile-pdf.pdf.

22. MeSH Browser [database on the Internet]. EQUIA® Forte bulk fill, fluoride releasing glass hybrid restorative system. [cited $2018 \mathrm{Apr}$ 24] Available from: http://www.gcamerica.com/ products/operatory/EQUIA_Forte/EQUIA_Forte_Sell_Sheet_US2016-iPad.pdf.

23. Gorseta K, Glavina D, Skrinjaric T, Czarnecka B, Nicholson JW. The effect of petroleum jelly, light-cured varnish and different storage media on the flexural strength of glass ionomer dental cements. Acta Biomater Odontol Scand. 2016 Mar 29;2(1):55-9.

24. Lohbauer U, Krämer N, Siedschlag G, Schubert EW, Lauerer B, Müller FA, Petschelt A, Ebert J. Strength and wear resistance of a dental glass-ionomer cement with a novel nanofilled resin coating. Am J Dent. 2011;24(2):124-8.

25. Baloch F, Mirza A, Baloch D. An in-vitro study to compare the microhardness of glass ionomer cement set conventionally versus set under ultrasonic waves. Int J Health Sci (Qassim). 2010 Nov;4(2):149-55.

26. Bala O, Arisu HD, Yikilgan I, Arslan S, Gullu A. Evaluation of surface roughness and hardness of different glass ionomer cements. Eur I Dent. 2012 Jan;6(1):79-86.

27. Shintome LK, Nagayassu MP, Di Nicoló R, Myaki SI. Microhardness of glass ionomer cements indicated for the ART technique according to surface protection treatment and storage time. Braz Oral Res. 2009 Oct-Dec;23(4):439-45.

28. Hankins AD, Hatch RH, Benson JH, Blen BJ, Tantbirojn D, Versluis $A$. The effect of a nanofilled resin-based coating on water absorption by teeth restored with glass ionomer. J Am Dent Assoc. 2014;145(4):363-70.

29. MeSH Browser [database on the Internet]. GC America. G-Coat Plus nanofilled, self-adhesive, light-cured protective coating. [cited 2018 Apr 24] Available from: www.gcamerica.com/products/ operatory/G-Coat_Plus/GCoatPlus_Product Brochure.pdf.

30. Ngo H, Mount GJ, Peters MC. A study of glass-ionomer cement and its interface with enamel and dentin using a low-temperature, high-resolution scanning electron microscopic technique. Quintessence Int. 1997 Jan;28(1):63-9. 